Marketing chain analysis: the case of agri-food traded in the public market

\title{
Análise dos canais de comercialização: o caso dos produtos agroindustrializados no mercado público
}

\author{
Andréa Cristina Dorr \\ andreadoerr@yahoo.com.br \\ Doutora em Economia pela Universität Leibniz Hannover/Alemanha \\ Professora Adjunta do Departamento de Ciências Econômicas da Universidade Federal de \\ Santa Maria/Brasil e Coordenadora do Grupo de Pesquisa em Agronegócio \\ Maykell Leite da Costa \\ maykellcosta@gmail.com
}

Engenheiro Agrônomo pela Universidade Federal de Santa Maria/Brasil e estudante de pósgraduação em Extensão Rural pela mesma instituição

Marcos Alves dos Reys

$\underline{\mathrm{m} \text { reys@ } @ \text { hotmail.com }}$

Dr. Sc. Agr. pela universidade de Hohenheim/Alemanha. Professor adjunto departamento de educação agrícola e extensão rural (DEAER/ Brasil) da Universidade Federal de Santa

Maria/Brasil

Editor Científico Responsável Prof ${ }^{a}$ Ana Akemi Ikeda Prof $^{a}$ do departamento de Administração FEA/USP/Brasil

Recebido em: 26/01/2010

Aprovado em: 20/08/2010

\section{Resumo}

A cadeia de frutas frescas está focando de forma crescente no valor adicionado e na redução de custos, procurando atender a demanda do consumidor. A cadeia de produtos agroindustrializados no mercado público do município de Santa Rosa (estado do Rio Grande do Sul, Brasil) é um caso particular para analisar a importância dos custos de transação com o intuito de produzir com mais eficiência. $O$ artigo tem como objetivo verificar o funcionamento da cadeia de mercado e analisar a percepção dos produtores entrevistados em relação à segurança alimentar, rastreabilidade e certificação. O artigo também propõe uma análise do tipo de governança utilizado na referida cadeia com relação às características transacionais. O referencial teórico baseou-se nos conceitos da Cadeia Global de Valor. Apesar da estrutura de governança ser caracterizada como de mercado, os canais de comercialização de produtos agroindustrializados comercializados no mercado público de Santa Rosa-RS são bem coordenados. No entanto, os produtores precisam aumentar seus níveis de percepção e se familiarizar em relação aos assuntos ligados à segurança do alimento, rastreabilidade e certificação. Políticas públicas são necessárias para prover um sistema de monitoramento e assistência aos produtores. 
Palavras-chave: canais de comercialização, pequenos produtores, certificação, rastreabilidade, segurança do alimento

\begin{abstract}
:
The fresh fruit marketing system is increasingly focused on adding value and decreasing costs by streamlining distribution and understanding customer demands. Agri-food marketing chains in the Public Market in the municipality of Santa Rosa (State of Rio Grande do Sul, Brazil) offer a particularly challenging setting for the analysis of the importance of transaction costs for production efficiency and supply chain efficiency. This paper aims to verify the functioning of the marketing chain and to evaluate the perception of the surveyed farmers with regard to food security, traceability and certification. It also proposes an analysis of the type of governance used in this value chain regarding the characteristics of transactions. The theoretical background is based on the concepts of the Global Value Chain approach. Although the governance structure is characterized as market, the marketing chain of agrifood products traded in the public market in the municipality of Santa Rosa-RS presents a good coordination. Nevertheless, farmers need to increase their level of perception and become familiar with regard to issues related to food safety, traceability and certification. Public policies are called for providing management monitoring and assistance for the farmers.
\end{abstract}

Key-words: marketing chain, smallholders, certification, traceability, food safety

\title{
1. INTRODUCTION
}

Fresh fruits and vegetables are examples of traditional agricultural export crops and they illustrate the potential for agricultural diversification and production of high-value crops. These sectors are seen as sectors where small producers are able to participate due to their low demand on land and their high labor requirements. Since fruits and vegetables are perishable, disastrous quality losses can occur at any stage in the marketing chain from grower to consumer and the total value of the product may be lost. Hence, every activity in the production and marketing chain of fruits must be precisely timed (JENSEN e RORABAUGH, 2007).

Nevertheless, food safety standards can also have positive implications for developing countries. These countries may gain and maintain access to markets of high-value agricultural and food products, especially in industrialized countries (HENSON e JAFFEE, 2007). From this standards-as-catalyst angle, the challenge inherent in compliance with food safety and agricultural health standards may well provide a powerful incentive for the modernization of developing countries export supply chains and give greater clarity to the necessary and appropriate management functions. Further, via increased attention to the spread and adoption of good practices in agriculture and food manufacture, there may be spillovers into domestic food safety and agricultural health to the benefit of the local population and domestic producers. Hence, part of the costs of compliance could be considered as investments into the national economy.

Rather than degrading the comparative advantage of developing countries, enhancement of capacities to meet stricter standards could potentially create new forms of competitive advantage. Hence, the process of standards compliance could conceivably provide the basis for a more sustainable and profitable trade over the long term, albeit with some particular winners and losers (HENSON e JAFFEE, 2004). 
Producers of fresh fruits and vegetables from developing countries like Brazil are increasingly required to demonstrate the safety and traceability of their produce up to the consumption stage. There is some evidence in the literature, that certification contributes positively to the development of specific sectors in developing countries. For example, standards may open new opportunities as they permit access to particular market segments. However, certification may also have the effect of a non-tariff trade barrier, undermining the capability and financial ability of especially small-scale farmers in exporting to international markets.

The Public Market located in the city center of municipality of Santa Rosa (State of Rio Grande do Sul, Brazil) was created in 1988. Its main function is related to the possibility that rural farmers on the municipality could be able to sell their products directly to consumers. In this sense, the Public Market plays not only an economic role but also a social one. Entering a new local into the public market could be considered a major challenge for many farmers in the municipality of Santa Rosa-RS. New skills and knowledge are demanded, mainly related to bureaucratic procedures, logistics procedures and consumers' tastes. Upgrading could facilitate and promote competitiveness to access this public market.

This paper focuses on the level of perception and awareness of the small rural farmers in the municipality of Santa Rosa-RS, Brazil with regards the importance of traceability, food security and certification of their products sold in the public market. In addition, it aims to understand the functioning of the marketing chain as a tool to enhance local development. We make use of the Value Chain analysis in order to support theoretically this paper. It is one of the most prominent approaches to analyze changing market structures and to develop suitable strategies for private sector development in developing countries. Several studies based on Global Value Chain (GVC) theory have been developed. In the 1990s the concept of value added chains emerged as an approach to analyze and explain new forms of international trade. Certification schemes are used to ensure marketing claims for unobservable quality attributes and under asymmetric information, to guarantee process-oriented quality characteristics.

\section{LITERATURE REVIEW}

\subsection{Certification: definition and purposes}

Certification is a procedure by which a third party gives written assurance that a product, process or service is in conformity with certain standards. Thus, certification can be seen as a form of communication along the supply chain while the certificate demonstrates to the buyer that the supplier complies with certain standards (BECK, 2003). Similarly, "certification is the (voluntary) assessment and approval by an (accredited) party on an (accredited) standard" (MEUWISSEN et al., 2003: 54). SCHIEFER (2003: 4) mentions that "sustainable and effective certification must allow clearly identifiable segmentation through, e.g., branding of products from clearly specified supply chains".

In the agricultural and food industry sector, certification refers to all kinds of food products (juices, cereals and grain incl. rice, and even alcoholic beverages (wine etc.), sugar, meat, dairy products or eggs) which have been produced based on organic or bio-dynamic farming technologies or on Integrated Pest Management (IPM). Other non-food agricultural products like animal feeds (for production of organic meat, dairy products and eggs), grain seeds, natural pesticides and insecticides, cosmetics and textiles (cotton, leather and leather goods) may also be certified if they meet certain environmental criteria (BASU et al., 2004).

According to EL-TAWIL (2002), certification is the process by which buyers assess the compliance with defined standards and is typically undertaken by a third party agency that the buyer recognizes as competent. A crucial issue for low and middle-income countries is the establishment of certification capacity and parallel institutions through which certification bodies are accredited.

The purpose of certification is to reach a defined performance and to make this perceptible to stakeholders. Stakeholders may include consumers, other customers, governments, risk- 
financing parties such as banks and insurance companies, or society as a whole. Also the company itself can be a stakeholder, since certification of food safety and traceability systems gives organizations a tangible approval of good practice and a tool for due-diligence defense in case of product safety (HENSON e HOLT, 2000). For stakeholders to regard certification as a valuable tool, they must trust the certification scheme as well as the certifying party. Also, there should be regular tests or audits (usually specified in the certification scheme) to verify whether the certified party still reaches the agreed performance level.

On the one hand, implementing food safety standards can increase costs for firms. On the other hand, firms have incentives to protect their reputation (ZINCO et al, 2007), and so might implement state-of-the-art food safety practices without any prodding from the government. Additionally, as consumers might be willing to pay more for food that they perceive as safer (ARYAL et al., 2009; LAROCHE et. al., 2001), firms have another incentive to implement stricter food safety regimes. The higher prices consumers are willing to pay could compensate firms for the costs of food safety provision. A firm will adopt more stringent food safety practices if the cost is smaller than the resulting benefit to the firm in the form of reduced risk of losses, reduced liability, and higher consumer willingness to pay for the safer food (MITCHELL, 2003).

Certification can act to impede exports either because explicit bans are placed on imports of particular products or the cost of compliance with requirements diminishes export competitiveness. Standards can therefore be a source of competitive advantage for the developing countries if they upgrade capacity and make the necessary adjustments in the structure and operation of their supply chains. For many high-value foods, including fruits and vegetables, the challenges of international competitiveness have moved beyond price and basic quality parameters to greater emphasis on food safety. Indeed, rising food safety standards serve to accentuate supply chain strengths and weaknesses and thus, affect the competitive positions of countries and distinct market participants (HENSON e JAFFEE, 2004).

\subsection{Different types of standards}

Setting international standards has proven difficult due to the variety of circumstances that exist around the world. This is especially true for agricultural products, which have to respond to differences in climate, soils and ecosystems and are an integral part of cultural diversity. Environmental and social standards are hence, often normative standards, i.e. generic standards or guidelines used as a framework by local standard-setting or certification bodies to formulate more specific standards. Nevertheless, standards developed in one particular country or geographical area may discriminate against producers of other countries or areas if they do not take into account different local conditions (FAO, 2003).

The most widely-applied general standards systems are the Hazard Analysis Critical Control Points (HACCP) and ISO 9000 required by the food industry. The HACCP system identifies specific hazards and establishes control systems that focus on prevention rather than on endproduct testing. In contrast, ISO standards are specific to a particular product, material or process. ISO 9000 examines if regulations for items are met. Thus, HACCP is a food safety meta-system and ISO 9000 is a quality management system. Both systems are applied by the processing food industries (LEE, 2006).

HOBBS, FEARNE e SPRIGGS (2002) compare the incentive structures in the food safety legislation and business strategies in the private sector in the United Kingdom (UK), Canada and Australia. The comparisons highlight the importance of incentives for changes in determining the respective roles of public policy and private sector responses to food safety issues.

HENSON (2006) distinguishes between standards as being mandatory, voluntary and de facto. Mandatory or regulatory standards, named technical regulations by the Technical 
Barriers to Trade (TBT) Agreement, are standards set by public institutions whose compliance is obligatory in the legal sense. Voluntary consensus standards arise from a formal coordinated process involving participants in a market with or without the participation of the government. Finally, de facto standards arise from an uncoordinated process of market-based competition of private firms. These standards refer to a set of specifications to gain market share through authority or influence.

According to SCHULZE et al. (2006), there are public and private certification systems. Governmental certification systems, for instance, serve the consumer's protection purposes by providing quality labels to improve market transparency (e.g., organic farming). Public certification systems help to prevent mislabeling through laws and fines enforced by public authorities. However, most certification schemes are privately organized. Certification procedures tend to be different depending on the purposes: either for consumer marketing or to meet the demands of institutional buyers.

Likewise, the World Trade Organization (WTO, 2005) has also divided standards into private or public. The distinction between them matters when considering whose interests on standards are set for. It is assumed that interests of all actors in society are considered in the case of public standards, while the private standards are chosen to maximize firms' profits. Thus, private standards are by definition voluntary, but public ones can be either voluntary or mandatory1.

\subsection{Information asymmetries}

Information asymmetries (VERTINSKY e ZHOU, 2000) occur when producers have information about the characteristics of the goods they produce which the consumers do not possess. Buyers are in a disadvantageous position compared to sellers, because the latter are well-informed about the goods or services as opposed to the buyers. Therefore, standards can increase welfare by removing information asymmetries in markets (WTO, 2005). Thus, the existence of asymmetric information increases the transaction costs on the one hand, and on the other, generates private incentives to decrease them. Moreover, food quality and safety standards are voluntarily accepted and applied by the firms to improve their competitiveness. This motivation guides the firms towards quality assurance systems (HOLLERAN et al., 1999).

The idea behind certification systems is to reduce existing information asymmetries, especially in the case of goods including credence attributes such as food safety, organic production and animal welfare. In the supply chain, consumers and suppliers are confronted with information uncertainty. Consumers are not able to detect opportunistic behavior. In order to reduce consumers' and suppliers' uncertainty, retailers and brand manufacturers tend to increasingly monitor their suppliers' production process themselves via second party audits (CASWELL et al., 1998).

An analysis of a certification system focusing on its functioning reveals that certification systems include tendencies towards opportunistic behavior. Taking into consideration the great number of customers demanding certificates from their suppliers, producers are constantly under pressure to certify (SCHULZE et al., 2006). MOREOVER, BECK e WALGENBACH (2003) emphasize that suppliers perceive certification schemes as externally imposed obligations instead of intrinsically motivated quality management systems.

JAHN, SCHRAMM e SPILLER (2005) denote that "certification systems and labeling imply multifaceted problems to which the parties involved have paid little attention so far: the central task of certification and the reduction of information asymmetry within the market can be fulfilled only if the institutions in charge succeed in assuring certification quality and thus,

\footnotetext{
${ }^{1}$ In WTO terminology mandatory standards are referred to as technical regulations under the Agreement on Technical Barriers to Trade and also sanitary or phytosanitary measures under the Agreement on the Application of Sanitary and Phytosanitary Measures.
} 
the validity of the audit signal". However, the reliability of the quality labels and their effectiveness strongly depend on the type of external audits and their implementation. Usually the control process is carried out by independent certifiers who, in turn, have to meet criteria settled by agencies. Only if the certifiers succeed in revealing critical aspects and opportunistic behavior, quality assurance concepts will be able to build up the reputation necessary to serve as a reliable quality signal (JAHN, SCHRAMM e SPILLER, 2005).

Depending on the information about the safety of the goods that is available to consumers, goods are classified into three categories. First, there are search goods. The consumer is able to obtain information about the safety of the good through inspection - consumers have nearly perfect information. The second category relates to experience goods. Consumers can get information on safety through repeated purchases or through reputations established by others. The third is credence goods. In this case, consumers cannot discern information on product safety, even after repeated purchases (ANTLE, 2001). MARETTE, CRESPI e SCHIAVINA (1999) observe that agricultural markets are working imperfectly due to asymmetric information, since the consumers lack perfect information about the product quality.

JAHN, SCHRAMM e SPILLER (2004) seek to investigate the audit quality of certification systems within the food sector, based on financial auditing. They assume that suppliers are not interested in the highest possible standard of inspection, but in acquiring a certificate as easily as possible. Since the risk of free rider behavior occurs, a strict inspection lowers the probability of successful certification. Therefore, suppliers have an incentive to select an auditor known to employ low inspection standards. Thus, certification systems offer a variety of incentives for inadequate inspections. The conclusion highlights that standards tend to be weak without a public regulation inspection. The authors also mention the factors influencing the audit quality. These are: effects on reputation (if there is no reputation, suppliers search for a certifier with low control efforts and inspection prices); protecting quasi-rents (the dependence of certification is diminished); intensifying liability (the quality of the certifier inspection increases) and improvement of inspection technology (certifiers can have varying levels of success with the same costs due to having different levels of know-how).

DEATON (2004) points out that third-party certifiers play an important role in the global food system. Third-party certifiers are external institutions that assess, evaluate and certify quality claims. The framework used by him highlights five concepts: uncertainty; information asymmetries; opportunistic behavior; divergences between private and social returns and signaling institutions. The benefits of third-party institutions result from their capacity to provide market signals. Indeed, the costs of receiving independent third-party certification are inversely related to a firm's product quality.

\section{THEORETICAL FRAMEWORK}

During the last decade, the concept of the value chain has been highlighted in the literature and widely discussed among researchers and policy makers. The value chain describes the full range of activities which are required to bring a product or service from conception through the different phases of production, delivery to final consumers, and final disposal after use.

\subsection{Value chain approach}

The concept of governance "[...] is central to the global value chain approach $[\ldots]$ the concept is used to refer to the inter-firm relationships and institutional mechanisms through which non-market co-ordination of activities in the chain takes place. This coordination is achieved through the setting and enforcement of product and process parameters to be met by actors in which developing country producers typically operate" (HUMPHREY e SCHMITZ, 2001). The authors use the concept of governance "to express that some firms in the chain set 
and/or enforce the parameters under which others in the chain operate. A chain without governance would be a string of market relations".

The determinants of governance presented by HUMPHREY e SCHMITZ (2000) are: arm's length market relations [buyer and supplier do not define the product; no long term relationship and the buyers' and producers' risks are low]; networks [the buyer and supplier define the product specifications together; the buyers' risk is minimized because of the suppliers' high level of competence]; quasi-hierarchy [high degree of control from buyers over suppliers; the former define the product] and hierarchy [buyers control the supplier production process]. The authors suggest that quasi-hierarchy is more likely to occur where global value chains frequently link producers in developing countries and retailers in developed countries.

Similarly, KEESING e LALL (1992) argue that producers in developing countries are expected to meet requirements that frequently do not apply to their domestic market. For instance, this creates a gap between the capabilities required for the domestic market and those required for the international one. This gap is widened when the buyers require consistent quality and supply, creating two reasons for quasi-hierarchical governance. The first refers to monitoring and control which might be required to ensure that products and processes meet the required standards. The second reason, in case the gap needs to be closed quickly, is that buyers will need to invest in a few selected suppliers and help them to upgrade. Mostly buyers have a higher interest in suppliers according to their relationships.

GEREFFI, HUMPHREY e STURGEON (2005) propose a more complete typology of value chain governance, divided into five types: (i) markets: market linkages can persist over time with repeated transactions - the cost of shifting the partner is low for both; (ii) modular value chains: suppliers make the products according to the customers' specifications, detailed more or less by the former; (iii) relational value chains: complex interactions among buyers and sellers, often creating mutual dependence and a high level of asset specificity; (iv) captive value chains: small suppliers are transactional dependent on larger buyers, characterized by a high degree of monitoring and control by lead firms, and finally (v) hierarchy: characterized by vertical integration.

In the same study, the authors develop a theory of value chain governance based on three factors: (i) the complexity of information and knowledge required to sustain a particular transaction with respect to product and process specifications, (ii) the extension in which knowledge and information are codified and transmitted efficiently, and (iii) the capabilities of actual and potential suppliers regarding the requirements of the transaction.

An analysis of marketing channels and upgrading strategies for fresh fruit and vegetables shows how the development of niche markets for high-value produce creates new opportunities for producers. New marketing channels have opened up as a result of a combination of changing consumer tastes. The identification of opportunities for adding value and the development of strategies to take advantage of them are based on an analysis of the changing governance structures of food value chains.

Figures 1 shows the marketing chain of the rural farmers who trade products in the Public market in the municipality of Santa Rosa-RS. The chain includes the characteristics of the farms, type of product, the packing procedure, and means of transportation until the final destination at the public market for consumption. All stages play a positive and significant role towards its coordination. The variables shown bellow will presented and discussed in the next topic. 


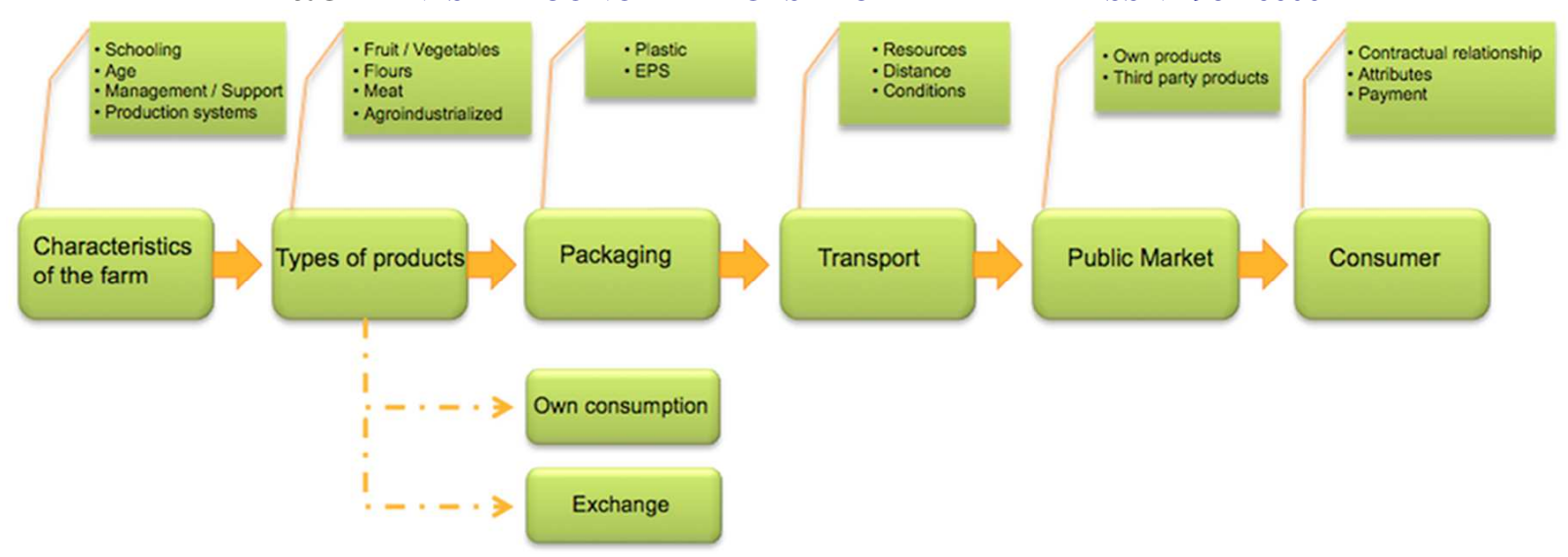

Figure 1 - Conceptual framework of the marketing chain

Source: Designed by the authors

\subsection{Empirical evidences on marketing chain}

Fruit are of high value and perishable and once harvested they continue to ripen; however, the process can be delayed only slightly with refrigeration. Consequently, disastrous quality losses can occur at any stage in the marketing chain from grower to consumer and the total value of the product may be lost. Therefore, every activity in the production and marketing chain must be precisely timed (JENSEN e RORABAUGH, 2007). There are many different marketing chains for fruits and vegetables and differ among countries, crops and farmers. The most important stage to understand is the fist link in the production or so called marketing chain, between the farmer and the trader (FAO, 1989).

The banana market structure is very heterogeneous, depending on the producing and importing countries. The presence of diverse economic actors is also different, among countries and regions, at the several stages of the banana chain. Due to the high level of perishability, bananas require a careful control of the growing, packaging, transport, ripening and distribution process. This leads to a highly vertically integrated banana sector, where large transnational companies tend to control from direct growing of bananas in producing countries, through ownership of specialized refrigerated shipping and ripening facilities to distribution networks in importing countries. An analysis of the banana marketing chain reveals that companies are facing the challenge of increasing role that is being played by supermarkets and retail chains in the distribution of bananas in developed countries, mainly in The US and EU. Supermarkets tend to build long-term relationships with preferred suppliers in order to guarantee a continuous supply at the required level of quality (UNCTAD, 2007a). Similarly, UNCTAD (2007b) developed a study on citrus marketing chain. The major supplier of orange juice is Brazil, while Europe is the major market for exports. According to the marketing chain, the most significant distribution channels for orange juice and fruit juices are the global retail chains, responsible for more than $80 \%$ of the total exported to Europe. CUELLER (2003) aimed to identify the current status of imported fruits and vegetables at retail, characterize the business practices of different participants involved in the supply chain and imported fruits and vegetables and identify challenges faced by these participants in marketing imported produce in The US market. The study reveal that the key issues in marketing of imported fruits and vegetables among retailers are food safety assurance, transportation cost reduction, quality improvement. Further, the key issues faced by exporters in marketing their products include improving packaging, adding value to products and assuring food safety.

\section{METHODS AND STUDIED AREA}


PUC Minas

The present work is part of a University Extension Project developed in the municipality of Santa Rosa/RS, Brazil. The city is located nearly $500 \mathrm{~km}$ far from the capital of Rio Grande do Sul state (Figure 2). The population estimated by Brazilian Institute of Geography and Statistics (Instituto Brasileiro de Geografia e Estatística - IBGE) in 2009 is 66.059 inhabitants and its area is $488 \mathrm{Km}^{2}$.

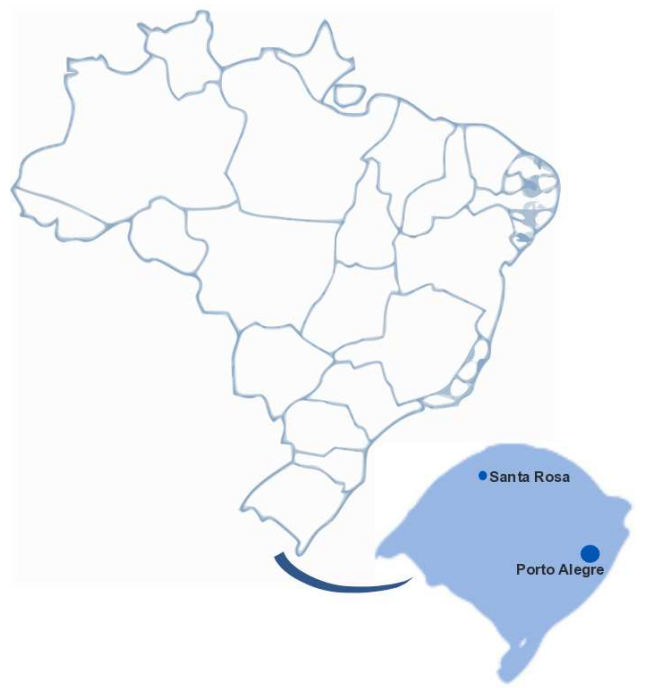

Figure 2 - Location of Santa Rosa /RS, Brazil.

Source: Designed by the authors

This research is part of the Rural Development Project which is a partnership between Federal University of Santa Maria (UFSM) and Santa Rosa Municipal government, since 2007. This partnership between the institutions was accomplished after several meetings with representatives of the Applied Rural Extension Group and The Municipal government of Santa Rosa. It is important to mention that many difficulties were faced mainly political and economical ones, which were solved after many negotiations. This integration brought more liability to the project from the public target of the project- the family farmers.

A data collection was composed of a structured interview applied to a sample of 20 small farmers who trade their products at the local public market in September 2009. The producers were selected randomly, based on a population of 54. In general, sample size depends on variables and statistics confidence levels. To ensure that this sample population could yield significant results from econometric analysis, a statistical power analysis was made to determine the sample size, whereby expected effect size, i.e., expected differences of means of two populations or the alternative hypothesis, can be detected with a certain power and significant level. This approach requires information on population means $(\mu)$ and standard deviation $(\sigma)$ based on lists of producers. The sample size of each stratum was calculated using the program Russlenth ${ }^{2}$.

The questionnaire was developed through pre-testing of each question via personal interviews with producers. The interviewed individuals were asked to state their interpretations of a series of suggested questions. According to Yin (1994), interviews are considered one of the most important sources of case study information. There are several forms of possible interviews: open-ended, focused and structured or survey types. In open-ended interviews, key respondents are asked to comment on certain events. In focused interviews, the interviewer asks a set of questions in a short period of time. In the third type of structured interviews, the researcher organizes and details the questions in advance.

\footnotetext{
${ }^{2}$ Available on the website: http://www.cs.uiowa.edu/ rlenth/Power/ (Accessed on August 2009)
} 
Data cleaning was conducted after the data entry. It implies detecting and removing errors and inconsistencies in order to improve data quality. Usually, data quality problems are present in single data collections due to spelling mistakes during data entry, missing information or other invalid responses. The major purpose of cleaning data is to identify overlapping data, in particular by matching records referring to the same farmer. In general, data cleaning involves two steps: detection and correction of errors in a data set. Errors were detected using mainly three procedures: descriptive statistics, scatterplots and histograms.

For the quantitative and quantitative analyses of the descriptive statistics in this survey, t-test and the correlation analysis have been applied at $90 \%$ confidence level. All analyses were performed using SPSS software.

\section{RESULTS}

This section analyzes the primary data deriving from the field survey, i.e. 20 small farmers. The descriptive statistics statistically significant at $1 \%, 5 \%$ or at $10 \%$ level and considered the standard deviation and the mean.

It is structured according to the property and social characteristics, type of marketed products, how the packaging is done, transportation features, the origin of sold products and seller's relationship with the consumer. Firstly, Figure 1 presents the functioning of the marketing chain of the products sold in the Public Market. The respondents ' social data indicate that the mean age of producers is 46,7 years and $75 \%$ have only four years of schooling. According to DORR (2009), the low level of schooling leads to greater difficulty in implementing managerial techniques in the property, which in turn makes difficult the traceability of the chain.

It comes out that in the researched reality that schooling is inversely proportional to the annual gross income. It was found that on average properties where schooling is four years, the annual gross income ${ }^{3}$ is twice that where the average age is twelve years (Graph 1). In this way, it is noted that this chain, the field experience of producers and the property organization are more important than schooling for income generation. In addition, data show that only $10 \%$ of the producers interviewed have some kind of management of their production costs. The same happens with transportation and sales costs.

The arguments for this lack of management are directly linked to lack of interest, followed by lack of time. In this way, it is noted that the lack of interest is due mainly to the fact that there are few management tools that are adapted to the realities of rural producers. As the Administration is not a usual practice, the annual gross income can be high, but one must know the production costs, otherwise there is the risk of not being having profitability in the activity.

Results show that $90 \%$ of the public market producers sell their own products, and only $10 \%$ commercialize their own and third parties. In addition, it was found that there is a diversification of products sold. One can remark the variety of fruits, legumes and vegetables, followed by powdered and sausage. It also found that for $45 \%$ of the families involved, the public market is the main source of income. In addition, $60 \%$ of the respondents consider the activity in public market as very important, while the remaining assessed it as" important". In this way, the importance of effective management of the entire chain is highlighted.

\footnotetext{
${ }^{3} € 1,00=\mathrm{R} \$ 2,25$ at the time of data collection
} 


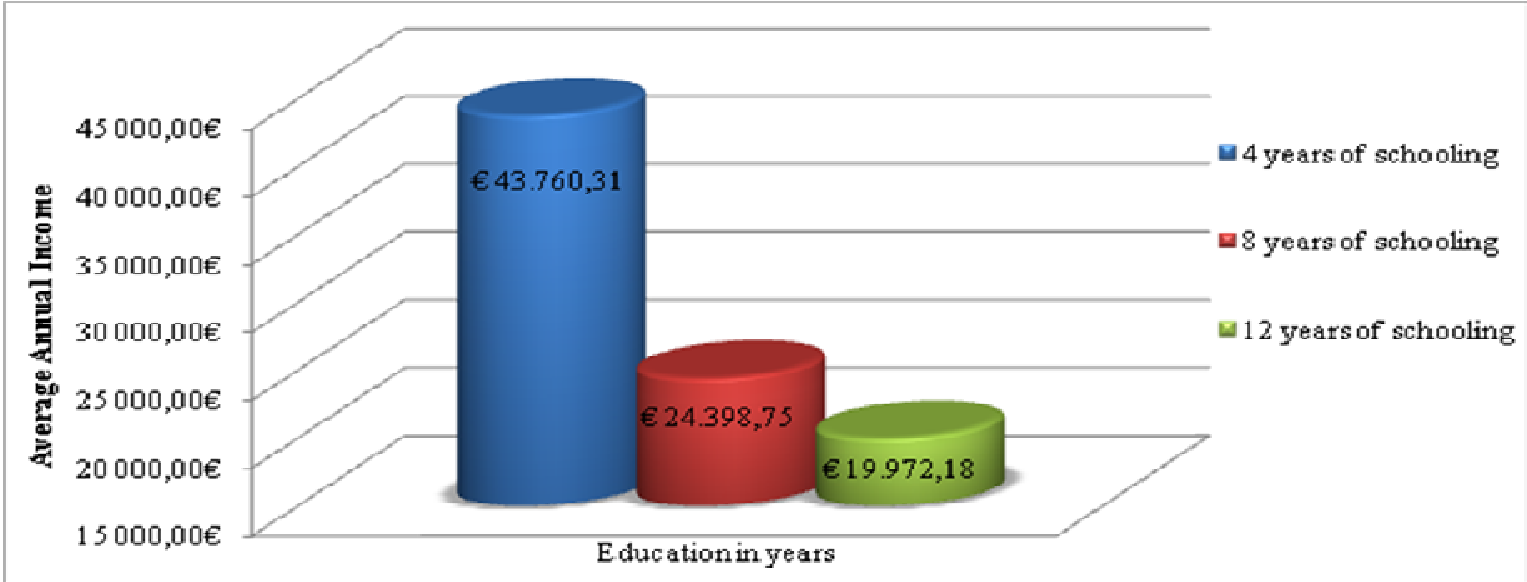

Graph 1- Gross average income compared to years of schooling of the rural farmers of the municipality of Santa Rosa-RS in 2008.

Source: Designed by the authors

It was observed that $60 \%$ of the producers use plastic packaging for vegetable and fruits, while $20 \%$ use plastic packaging for powdered products. These figures show the concern of the salespeople with the preservation of products. From the interviewed producers, $100 \%$ carry your products until the market with their own vehicle. Of these, $40 \%$ believe that the conditions of access through the main road are good and 35\% consider it bad. Besides, the roads conditions accessing properties are considered good for $50 \%$ of respondents and bad by $30 \%$. The average distance of the property until the public market is $9.3 \mathrm{~km}$.

In relation to the pricing of products sold in the public market, the results show that $42 \%$ of the producers make up the price based on the price stipulated by other sellers in the public market. However, $32 \%$ informed that make up the price based on prices in the local trade. Only $16 \%$ say that price is formed on the basis of production costs. This statement points again to the question of management, as producers do not perform the managerial control, there are not the possibilities to form the prices based on the production costs, which leads to uncertainty about the net profitability of the activity.

Analysis of the data showed that a significant number of producers has no knowledge about what is traceability, certification and food security, as shown in Graph 2. This is worrying, having in mind that consumers are increasingly concerned with the quality and origin of the products they buy.

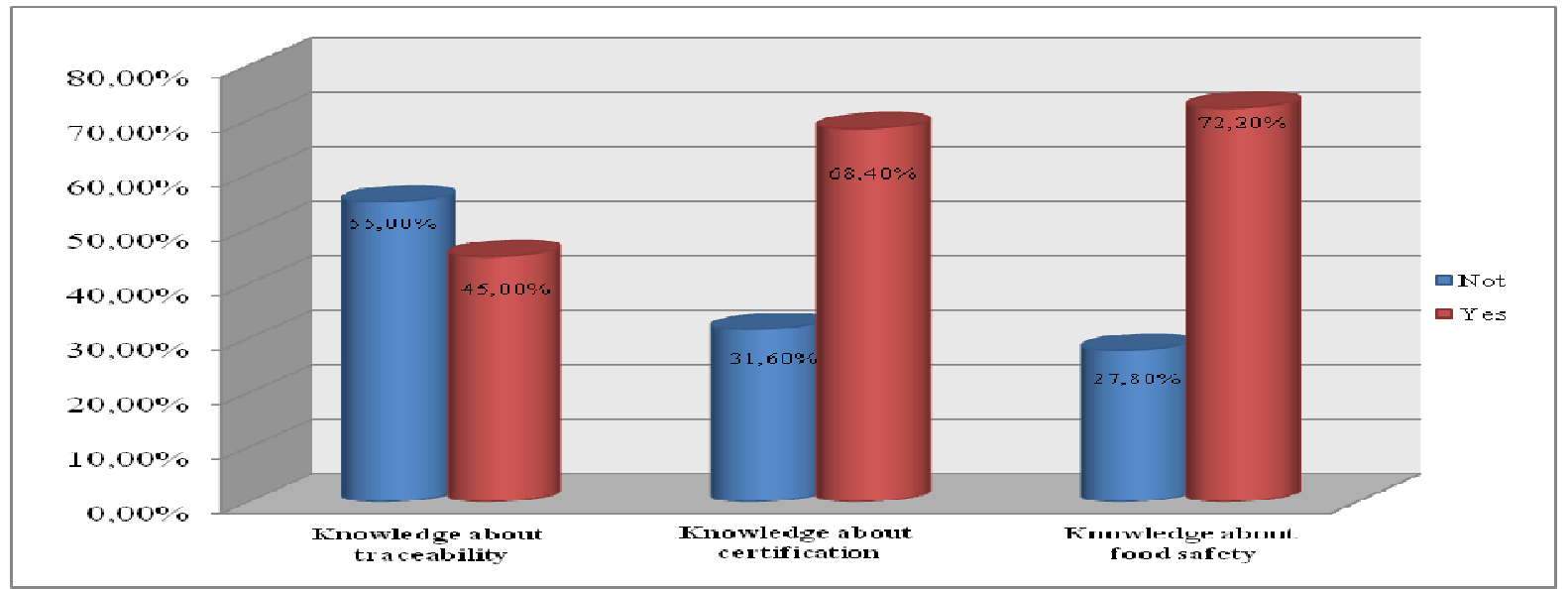

Graph 2- Level of knowledge of farmers with regards to traceability, certification a food safety.

Source: Designed by the authors. 
In spite of the concern regarding the results about the level of knowledge of farmers in relation to traceability, certification and food security, surprisingly enough, they mostly consider these variables as important or very important (Graph 3). This demonstrates that actions related to the improvement of quality and traceability of products, provided that they are implemented for the realities of family producers, tend to be well accepted and put into practice by family farmers.

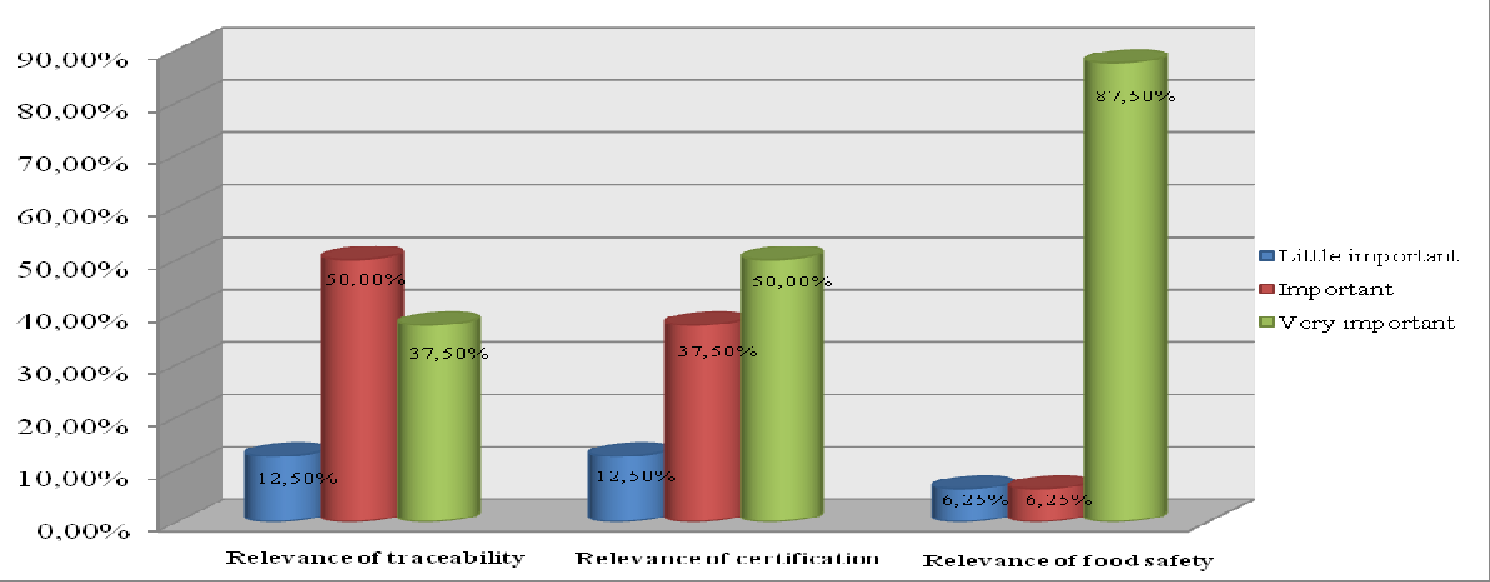

Graph 3 - Level of relevance of traceability, certification and food safety on the farmers' perspective.

Source: designed by the authors

It was noted that more than $60 \%$ of consumers consider the quality of the products, the health control, and best practices as fundamental factors for their purchases. Nevertheless, in the local reality, it is still important the number of consumers with a price-driven behavior. This indicates that farmers should be able to sell the products of good quality and with an affordable price. What can only be achieved through strict managerial control.

The results show that $100 \%$ of consumers purchase the products in cash on the public market. In this way, it is noted that the governance structure that persists between buyer and seller characterized as market, i.e. market linkages where can persist over time with repeated transactions.

\section{Conclusion}

In conclusion the marketing chain of agri-food products traded in the public market in the municipality of Santa Rosa-RS is well-coordinated. Although the governance structure is characterized as market, it plays an important role with regards the coordination of the chain. The marketing of agricultural and agro-industrialized products are very important in generating income for producers. In addition, this activity allows the permanence of farmers in the field. There is a need of producers to become familiar with regard to matters relating to food safety, traceability and certification, in view of the increasing concern for consumers with the quality and origin of products consumed. It was recognized the need for the use of a management system to register the cost of production, transport and sales, which must meet the characteristics of family farmers, while respecting their degree of knowledge and technological constraints. Also public policies that provide management monitoring and assistance for the producers are called for.

\section{References}

ANTLE, J. Economic Analysis of Food Safety. In: Gardner, B.; Rausser, G. (Eds). Hanboock of Agricultural Economics. v. 1. 2. p. 1083-1136. 2001. 
ARYAL, K. P.; CHAUDHARY, P.; PANDIT S.; SHARMA, G. (2009) Consumers' willingness to pay for organic products: a case from Kathmandu Valley. The Journal of Agriculture and Environment. v. 10. p. 12-22. jun. 2009.

BASU, A.; CHAU, N.; GROTE, U. On Export Rivalry and the Greening of Agriculture - The Role of Eco-labels. Agricultural Economics, v. 31, issue 2-3, p.135-147. 2004.

BECK, N.; WALGENBACH, P. ISO 9000 and Formalization - How Organizational Contingencies Affect Organizations Responses to Institutional Forces. Schmalenbach Business Review. V.55-4. pg. 293-320. 2003.

CASWELL, J.A.E.; BREDAHL, M.E.; HOOKER, N.M. How Quality Management Systems are Affecting the Food. In: Review of Agricultural Economics 20-2. p. 547-557. 1998.

CUELLER, S. Marketing Fresh Fruit and Vegetables Imports in the United States: Status, Challenges and Opportunities. Smart Marketing Newsletter. p.3. March. 2003.

DEATON, B.J. A Theoretical Framework for Examining the Role of Third-party Certifiers. Food Control. 15. p. 615-619. 2004.

DORR, A. C. Economic Analysis of Certification in the Brazilian Fruit Chain. Göttingen: Cuvillier Verlag Göttingen. p. 224. 2009.

EL-TAWIL, A. An In-depth Study of the Problems by the Standardizers and other Stakeholders from Developing Countries - ISO/ WTO regional workshops: 1, International Organization for Standardisation. Geneva. 2002.

FAO. Horticultural Marketing - a Resource and Training Manual for Extension Officers. FAO Agricultural Services Bulletin 76. Rome, Italy. 1989. Available in: <http://www.fao.org/docrep/S8270E/S8270E05.htm> (Acessed: October 2007).

FAO. Environmental and Social Standards, Certification and Labeling for Cash Crops. Rome. p. 120.2003.

GEREFFI, G.; HUMPHREY, J.; STURGEON, T. The Governance of Global Value Chains. Review International Political Economy 12-1. p. 78-104. 2005.

HENSON, S.; HOLT, G. Exploring Incentives for the Adoption of Food Safety Controls: HACCP Implementation in the U.K. Dairy Sector. Review of Agricultural Economics. v. 222. p. 407-420. 2000.

HENSON, S. The Role of Public and Private Standards in Regulating International Food Markets. IATRC Summer Symposium "Food Regulation and Trade: Institutional Framework, Concepts of Analysis and Empirical Evidence". Bonn, Germany. 2006.

HENSON, S.; JAFFEE, S. Standards and Agro-Food Exports from Developing Countries: Rebalancing the Debate. World Bank Policy Research Working Paper n. 3348. 2004. 
HENSON, S.; JAFFEE, S. Developing Country Responses to the Enhancement of Food Safety Standards. In: Grote, U.; Basu, A.K.; Chau, N.H. (Eds). New Frontiers in Environmental and Social Labeling. Physica-Verlag. p. 193-220. 2007.

HOBBS, J.F.; FEARNE, A.; SPRIGGS, J. Incentive Structures for Food Safety and Quality Assurance: an International Comparison. Food Control. v. 13-2. p. 77-81. March. 2002.

HOLLERAN, E.; BREDAHL, M.E.; ZAIBET, L. Private Incentives for Adopting Food Safety and Quality Assurance. Food Policy. v. 24. p. 669-683. 1999.

HUMPHREY, J.; SCHMITZ, H. Governance and Upgrading in Global Value Chains. Paper for the Bellagio Value Chain Workshop. 2000.

HUMPHREY, J.; SCHMITZ, H. Governance in Global Value Chains. IDS Bulletin. v. 2. n. 3. 2001.

IBGE: Instituto Brasileiro de Geografia e Estatística. 2009. Available in: <http://www.ibge.gov.br/cidadesat/topwindow.htm?1> (Acessed: january 2009).

JAHN, G.; SCHRAMM, M.; SPILLER, A. Trust in Certification Procedures: an Institutional Economics Approach Investigating the Quality of Audits Within Food Chains. In: International Food and Agribusiness Management Association (IFAMA). 2004.

JAHN, G.; SCHRAMM, M. SPILLER, A. The Reliability of Certification: Quality Labels as a Consumer Policy Tool. Journal of Consumer Policy. v. 28. p. 53-73. 2005.

JENSEN, M.; RORABAUGH, P. Growing Tomatoes Hydroponically. University of Arizona. 2007. Available in: <http://cals.arizona.edu/hydroponictomatoes> (Accessed: January 2010).

KEESING, D.; LALL, S. Marketing Manufactured Exports from Developing Countries: Learning Sequences and Public Support. In: G. Helleiner (ed). Trade Policy, Industrialization and Development. Oxford: Oxford University Press. 1992.

LAROCHE, M.; BERGERON, J.; BARBARO-FORLEO, G. Targeting consumers who are willing to pay more for environmentally friendly products. Journal of consumer marketing. $\mathrm{v}$. 18. n. 6. p. 503-520. 2001.

LEE, G.C.H. Private Food Standards and Their Impacts on Developing Countries. European Commission. Trade Unit. 108 p. 2006.

MARETTE, S.; CRESPI, J.M.; SCHIAVINA, A. The Role of Common Labeling in a Context of Asymmetric Information. European Review of Agricultural Economics. v. 26-2. p. 167178. 1999.

MEUWISSEN, M.P.M.; VELTHIUS, A.G.J.; HOGEVEEN, H.; HUIRNE, R.B.M. Technical and Economic Considerations about Traceability and Certification in Livestock Production Chains. In: Velthius, A.G.J.; Hogeveen, H.; L. J. Unnevehr , Huirne, R.B.M. (Eds). New Approaches to Food Safety Economics. Kluwer Acad. Publ. Wageningen. p. 41-54. 2003. 
MITCHELL, L. Economic Theory and Conceptual Relationships between Food Safety and International Trade. Chapter 2. In: International Trade and Food Safety Economic Theory and Case Studies. Ed. Buzby, J.C. Agricultural Economic Report n. 828. p. 145. 2003. Available in: <http://www.ers.usda.gov/publications/aer828/> (Accessed: January 2010).

SCHIEFER, G. Traceability and Certification in Food Quality Production - a Critical View. In: Annet G. J. Velthius; H. Hogeveen; L. J. Unnevehr; R.B. M. Huirne (Eds). New Approaches to Food Safety Economics. Kluwer Acad. Pub. Wageningen. 2003.

SCHULZE, H.; ALBERSMEIR, F.; SPILLER, A.; JAHN, G. Checklist Governance: Riskoriented Audits to Improve the Quality of Certification Standards in the Food Sector. 16th Annual World Forum and Symposium "Agribusiness, Food, Health and Nutrition, IAMA Conference. Buenos Aires, Argentina. 2006.

UNCTAD. Banana. 2007a. Available in: <http://www.unctad.org/infocomm/anglais/banana/chain.htm> (Accessed: January 2008).

UNCTAD. Citrus Fruit. 2007b. Available in: <http://www.unctad.org/infocomm/anglais/orange/chain.htm> (Accessed January 2008).

VERTINSKY, I.; ZHOU, D. Product and process certification systems regulations and certification systems and international marketing strategies. International Marketing Review. v. 17. n. 3. p. 231-252. 2000.

WTO (World Trade Organization). World Trade Report 2005. Available in: <http://www.wto.org/english/res_e/booksp_e/anrep_e/world_trade_report05_e.pdf> (Accessed: December 2007).

YIN, R.K. Case Study Research: Design and Methods. Sage Publishing. Beverly Hills, CA. 1994

ZINCO, R.; FERRIS, G. R.; BLASS, F. R. ; LAIRD, M. D. Towards a theory of reputation in organizations. In: Research in Personnel and Human Resources Management Series. v. 26. Elsevier. p. 163-204. 2007. 